\title{
Legal analysis of approaches to state and local regulation of tobacco advertising and sales in the US
}

\author{
Jack R Bierig, Susan A Weber, T Robert Scarborough
}

\section{Introduction}

State and local governments are increasingly regulating cigarette and tobacco use. They are issuing rules, for example, that restrict smoking in the workplace and in public buildings. The American Medical Association believes that state and local governments should be encouraged to become even more active in policing the promotion and sale of tobacco products. This memorandum therefore reviews some of the options available to these governments to restrict advertising and distribution of cigarettes, cigars, and loose tobacco.

In brief, the memorandum concludes that state and local governments have great latitude to restrict the sale of tobacco products. State and local governments also have significant authority to regulate the advertising and promotion of cigars and loose tobacco. These governments may also regulate the advertising and promotion of cigarettes in certain ways although any regulation must be carefully crafted to avoid conflict with federal law.

Part I of this memorandum discusses legislation that state and local governments may enact to limit the sale and distribution of tobacco products. Part II explains how state and local governments may regulate the advertising and promotion of such products to the extent permitted by federal law.

\section{Restrictions on the sale of tobacco products \\ TOTAL BAN ON SALES}

State and municipal governments that are considering more rigorous regulation of tobacco sales have a wide range of options available to them. Nearly 100 years ago, the Supreme Court made clear that regulationand indeed prohibition - of cigarette sales is within the powers of the states. In Austin vs Tennessee, the Court stated:

Without undertaking to affirm or deny their evil effects, we think it within the province of the legislature to say how far [cigarettes] may be sold or to prohibit their sale entirely ... provided no discrimination be used as against such as are imported from other States ... and there be no reason to doubt that the act in question is designed for the protection of the public health.

179 US $343,348-49$ (1900). ${ }^{1}$ See also Posadas de Puerto Rico Associates vs Tourism Co, 478 US 328, 346-47 (1986); Illinois Cigarette Serv Co vs City of Chicago, 89 F 2d 610, 612 (7th Cir 1937); Fagan vs Axelrod, 550 NYS 2d 552, 559 (NY Sup 1990).

BAN ON SALES TO MINORS

While a total ban on tobacco sales may not be politically feasible, state and local governments have almost uniformly enacted legislation intended to keep tobacco products out of the hands of minors. As of 1993, 47 states had enacted laws that prohibit the sale of tobacco products to persons under 18 years of age. However, only two - Florida and Vermont are actively enforcing youth access laws on a statewide basis. See Substance Abuse Prevention and Treatment Block Grants, 58 Fed Reg 45,156, 45,166, 45,168-69 (26 August 1993) (proposed regulations).

To improve that enforcement record, a new federal law requires states, as a condition for receipt of certain federal block grants, to restrict the sale and distribution of tobacco products to minors. See 42 USC $\$ 300 \mathrm{x}-26$. The federal government is expected to mandate more rigorous enforcement of youth access laws, possibly by requiring states to conduct inspections and sting operations to enforce these laws. See 58 Fed Reg at 45,156. The federal government may also require that states:

have in place other well-designed procedures for reducing the likelihood or prevalence of violations. Examples of well-designed procedures include a tobacco sales or distribution licensing system similar to that used for alcoholic sales, a graduated schedule of penalties for illegal sales or distribution culminating in loss of license, controls on tobacco vending machines in locations accessible to youth, publication of the names of outlets making illegal sales, and use of local enforcement to supplement central enforcement. (Id)

Some state and local governments are considering supplementing statutes that criminalize the sale of tobacco to minors with civil enforcement systems. Under such systems,

1 See Ragland vs McLane Co, 697 SW 2d 892 (Ark 1985) (statute prohibiting nonresidents from engaging in tobacco business in Arkansas violated Commerce Clause). 
police departments no longer bear the sole responsibility for enforcing tobacco sales and distribution laws. Rather, an additional government agency - such as the Department of Public Health, Revenue, Business Relations, or Liquor Control - is charged with enforcing laws prohibiting sale of tobacco products to minors. This agency is given the authority to conduct inspections and to impose civil sanctions such as fines or suspension of tobacco distribution licenses. See generally 58 Fed Reg at $45,168-69$.

RESTRICTIONS ON VENDING MACHINE SALES

To restrict youth access to tobacco even further, 21 states, the District of Columbia, and a number of municipalities had, as of 1993, restricted vending machine sales of cigarettes - either by banning such sales altogether or by limiting the location of such machines. See 58 Fed Reg at 45,170-71. See, eg, Bravo Vending vs City of Rancho Mirage, 20 Cal Rptr 2d 164 (Cal App 4th Dist 1993); Take Five Vending, Ltd vs Town of Provincetown, 615 NE 2d 576 (Mass 1993); CIC Corp vs Township of East Brunswick, 628 A 2d 753 (NJ Super AD 1993), affirmed, 638 A 2d 812 (NJ 1994). See also Illinois Cigarette Serv, 89 F 2d at 610 . Vending machine companies have challenged these laws on three grounds, but their challenges have generally failed.

First, the companies have alleged that restrictions on vending machine sales violate the equal protection clause of the Fourteenth Amendment because such laws are arbitrary, capricious, and not rationally related to their objective. However, the vending machine laws have consistently withstood this constitutional challenge. Reviewing courts have found vending machine bans to be a rational means of reducing cigarette sales to minors, CIC Corp, $628 \mathrm{~A} 2 \mathrm{~d}$ at $759-61$, and of promoting the public health, Take Five Vending, 615 NE 2d at 581-82.

Second, the vending machine companies have complained that bans or limits on cigarette sales deprive them of a property interest in their vending machine licenses without due process of law. This argument has also been unavailing. Courts have rejected the notion that government-issued cigarette vending machine licenses are constitutionally protected property. See Take Five Vending, 615 NE 2d at 581. See also Illinois Cigarette Serv, 89 F 2d at 613 (rejecting argument that prohibition on vending machine sales is tantamount to confiscation of property without due process of law).

Finally, vending machine companies have argued that local governments may not ban vending machine sales of cigarettes because such bans conflict with state law. The outcome of these cases depends on the law of the state in which they arise. In some jurisdictions, state regulation of the tobacco industry is so pervasive that local vending machine ordinances are deemed to conflict with, or are preempted by, state law. See, eg, Allied Vending vs Bowie, 631 A 2d 77 (Md 1993) (local vending machine ordinance preempted). See also Vatore vs Commissioner of Consumer Affairs, 596 NY S 2d 113 (NYAD 2d Dept) (same), leave to appeal granted, 624 NE 2d 696 (NY 1993). However, other courts have upheld local vending machine bans. See, eg, Bravo Vending, 20 Cal Rptr 2d at 164; Take Five Vending, 615 $\mathrm{NE} 2 \mathrm{~d}$ at 579-80; CIC Corp, $628 \mathrm{~A} 2 \mathrm{~d}$ at 756-59. These decisions make clear that - if state law allows it - a local ban on cigarette vending machines is a legal way of restricting the access of minors to cigarettes.

BANS ON SALES AT SPECIFIED LOCATIONS

Vending machine laws are not the only option available to state and local lawmakers. Total bans on the sale or distribution of tobacco products within a specified radius of school buildings have been enacted. See, eg, Iowa Code $\$ 453 \mathrm{~A} .39(2)$ (a) (banning distribution of cigarettes or tobacco products within "five hundred feet of any playground, school, high school, or other facility when such facility is being used primarily by persons under age eighteen"). Such bans are likely to be subject to the same challenges and analyzed in the same manner as vending machine laws. Consequently, they are likely to be upheld by the courts as a reasonable means of restricting youth access to tobacco. In this respect, a legislative finding that prohibiting tobacco sales within a reasonable distance from a school will reduce consumption of tobacco by minors would be helpful in sustaining the law against legal challenge.

Other limitations on tobacco sales may withstand review if they are adequately supported by appropriate research and legislative findings. For instance, a local government may decide to outlaw the sale of cigarettes at service stations, convenience stores, or other businesses likely to be patronised by under-age cigarette buyers. In considering legislation of this nature, legislators should determine whether there is a rational, factual basis for distinguishing between local businesses that would be permitted to continue selling cigarettes and those that would be subject to the ban. Further, specific legislative findings should be made, documenting the basis for enactment of such laws. See, eg, CIC Corp, $628 \mathrm{~A} 2 \mathrm{~d}$ at 755 (discussing the research conducted by the Township of East Brunswick, New Jersey, prior to enacting its vending machine ban). Taking these preliminary steps will increase the likelihood that a restriction on cigarette sales will be upheld in court.

\section{BANS ON FREE DISTRIBUTION}

Finally, some states and local governments have prohibited the distribution of free tobacco product samples. See, eg, Minn Stat $\$ 325 F .77$ subd. 4 (prohibiting free distribution of tobacco products outside of tobacco stores); DC Code \$6-920-1(a) (same); Utah Code \$76-10-111(2) (prohibiting free distribution of smokeless tobacco). The best justification for such prohibitions is that they are designed to 
prevent access by minors. See Ark Stat. 85-27-227(c) (prohibiting distribution of free tobacco products or coupons within 500 feet " of any playground, public school, or other facility when such facility is being used primarily by persons under eighteen"); Ga Code \$16-12-174(e) (same). After all, street corner distributors handing out samples in a crowd are not in a position to distinguish between minors and adults.

The tobacco industry has objected to bans on distribution of free samples but has not challenged such bans in court. If it were to bring such a challenge, the industry would most likely argue that a ban on free samples is preempted by the Federal Cigarette Labeling and Advertising Act ("Cigarette Act" or "Act"). See 15 US C \& 1334. As explained below, such a ban would have the best chance of surviving a challenge under the Cigarette Act if it is not limited to cigarettes, but rather applies to all products that may not legally be sold to minors. See infra at 11-12 \& n 5.

\section{Restrictions on the advertising of tobacco products}

State and local governments may also regulate advertising and promotion of tobacco products - although their authority in this regard is limited by federal law. State and local restrictions on tobacco advertising will withstand judicial review only if they meet two requirements. First, restrictions on cigarette advertising must not be preempted by the Cigarette Act, and restrictions on the advertising of other tobacco products must not be preempted by other applicable federal statutes. Second, any restriction on advertising must comport with the First Amendment to the US Constitution.

\section{FEDERAL STATUTES REGULATING TOBACCO ADVERTISING}

Cigarette advertising

Any discussion of state or local regulation of cigarette advertising must begin with the Cigarette Act. The Act establishes "a comprehensive Federal program to deal with cigarette labeling and advertising with respect to any relationship between smoking and health." 15 USC \$1331. The Act has two stated objectives : a) to inform the public of the dangers of cigarette smoking; and $b$ ) to protect commerce by imposing nationally uniform cigarette labeling and advertising regulations. Id

To achieve these two goals, section 4 of the Cigarette Act, 15 USC \$1333, sets forth national cigarette labeling requirements. Section 5 of the Act, 15 USC \$1334, bars state and local governments from establishing their own standards based on smoking and health for the advertising or promotion of cigarettes. ${ }^{2}$ It provides as follows:

(a) No statement relating to smoking and health, other than the statement required by section 1333 of this title, shall be required on any cigarette package. (b) No requirement or prohibition based on smoking and health shall be imposed under State law with respect to the advertising or promotion of any cigarettes the packages of which are labeled in conformity with the provisions of this chapter.

Id $\$ 1334$ (emphasis added). ${ }^{3}$ Thus, federal law prohibits states or their subdivisions from regulating cigarette advertising and promotion "based on smoking and health."

Significantly, this "preemption" provision is not all-encompassing. It does not reach state and local laws that regulate cigarette advertising or promotion on a basis other than the relationship between smoking and health. See Cipollone vs Liggett Group, Inc, 112 S Ct 2608, 2621, 2624 (1992). By limiting the scope of this provision, Congress preserved a certain degree of authority for state and local lawmakers. ${ }^{4}$

a. Billboard restrictions Accordingly, many state and local governments and government agencies (such as sports and transportation authorities) have enacted legislation orregulations that restrict certain local forms of cigarette advertising, such as billboards. For instance, some communities are barring cigarette billboards in sports facilities in order to shield young fans from tobacco advertising. The Metrodome in Minneapolis has such a ban. See US Department of Health \& Human Services, Reducing the health consequences of smoking: 25 years of progress, a report of the Surgeon General 513 (1989). Other communities - including Boston and San Franciscohave banned cigarette advertisements throughout their mass transit systems. To date, such laws generally have gone unchallenged.

2 The Act also outlawed cigarette advertising on television and radio. 15 USC $\$ 1335$.

${ }^{3}$ At face value, this provision appears to apply only to state regulation of cigarette advertising, not to regulation by local governments. However, the Act elsewhere defines "State" to "includ[e] any political division of any State". 15 USC $\$ 1332(3)$. Further, the legislative history of the Act expressly states that the preemption provision applies to counties and municipalities. See S. Rep No. 566, 91st Congr, 2d Sess, 1970 USCCAN 2652, 2663:

In some instances, counties or municipalities exercise their authority over advertising by local ordinances, or regulations, or even occasionally by resolution. In order to avoid the chaos created by a multiplicity of conflicting regulations, however, the bill preempts State requirements or prohibitions with respect to the advertising of cigarettes based on smoking and health. This preemption is intended to include not only action by State statute but by all other administrative actions or local ordinances or regulations by any political subdivision of any State.

Accordingly, the preemption provision would appear to apply to all state and local government units.

4 The provision does not affect state and local authority to regulate cigarette sales. The legislative history of the Cigarette Act states that the preemption provision "in no way affect[s] the power of any State or political subdivision of any State with respect to the taxation or the sale of cigarettes to minors, or the prohibition of smoking in public buildings, or similar police regulations". S. Rep No. 566, 91st Congr, 2d. Sess, 1970 USCCAN 2652, 2663. 
However, a recent federal court decision relies on the Cigarette Act to preempt a local law regulating cigarette advertising. See Vango Media, Inc vs City of New York, 829 F Supp 572 (SDNY 1993), appeal pending. More specifically, New York City adopted a local law governing the placement of tobacco advertisements in taxicabs. The law required "the display of a minimum of one public health message pertaining to the health dangers of smoking for every four tobacco advertisements." Id at 573.

The District Court enjoined enforcement of the law. Id In so ruling, the Court rejected an argument that the lawmakers who enacted the provision were actually concerned with the economic consequences of smoking. The Court explained:

[I]t is impossible to abstract Defendants' economic rationale from the Local Law's fundamental nature as a regulation based on smoking and health. The economic costs cited by the City Council are secondary; they occur only because of the ill effects of smoking on City residents' health. (Id at 582.)

The reasoning of the Vango court demonstrates that any state or local law directed at advertising or promotion must be carefully drawn to avoid the Cigarette Act's preemption of advertising laws "based on smoking and health."

A state or local law that restricts cigarette advertising is most likely to survive a preemption challenge if the restriction is part of a general exercise of the police power and is not limited to tobacco products - eg, a law that prohibits, within a specified distance from schools and other areas where youth congregate, billboards for advertising products that may not legally be sold to children. At least one state-Vermont-has considered legislation that would ban the use of cartoon characters in advertising for products that may not lawfully be purchased by minors.

That a law of this nature applies to all products that may not be sold to minors - and does not even mention cigarettes strengthens the argument that the law is not "based on smoking" and health. In these circumstances, a good argument can be made that the law is based on the state's interest in enforcing laws that ban underage drinking and smoking and is therefore not preempted. ${ }^{5}$

b. Litigation strategies Another approach - one that would not require the enactment of new laws - is to encourage state attorneys general

\footnotetext{
${ }^{5}$ A similar analysis applies to laws that restrict the distribution of free cigarette samples. The courts have not been asked to decide whether the Cigarette Act preempts state and local regulation of cigarette sampling. However, even if the Act preempts such laws when they are "based on smoking and health," the Act may not preempt laws that prohibit the free distribution of products that cannot legally be sold or distributed to minors. Such laws are based, not "on smoking and health", but on the government's interest in enforcing its own laws concerning the distribution of certain products to minors.
}

to sue cigarette companies under existing statutory and common law causes of action that prohibit deceptive business practices. In Cipollone vs Liggett Group, Inc, 112 S Ct 2608 (1992), the Supreme Court held that the Cigarette Act preempts state actions for fraudulent representation based on the theory that advertising - by glamourizing smoking "neutralized the effect of federally mandated warning labels." Id at 2623 (plurality); id at 2636-37 (Scalia J, concurring in judgment in relevant part). However, the Court held that claims based on allegedly false or fraudulent statements are not preempted. Id at 2623-24 (plurality); id at 2629-31 (Blackmun J, concurring in judgment in relevant part).

The latter theory was invoked in a California case challenging the Joe Camel advertising campaign. In Mangini vs RF Reynolds Tobacco $C o$, the plaintiff alleged that the Joe Camel campaign constitutes an unfair business practice under California law because it targets minors for the purpose of inducing and increasing their illegal purchase of cigarettes. The California Court of Appeals held that this theory is not preempted because it "is not 'based on smoking and health' but on a more general duty not to engage in advertising that is against public policy, oppressive and unscrupulous and harmful to consumers." $21 \mathrm{Cal}$ Rptr 2d 232, 244 (Cal App 1st Dist 1993).

On 30 June 1994, the California Supreme Court affirmed on the same rationale. 1994 WL 314406 (Cal 1994). The Court then stated:

As early as 1891, the legislature cared deeply enough about smoking and minors that it prohibited the sale of cigarettes to them, just as it had earlier banned minors from houses of prostitution and would later ban them from prizefights. For over a century, with a watchful eye, in its role as parent patriae, it has maintained a paternalistic vigilance over this vulnerable segment of our society. It is now asserted that plaintiff's effort to tread upon Tobacco Road is blocked by the nicotine wall of congressional preemption. The federal statute does not support such a view. Congress left the states free to exercise their police power to protect minors from advertising that encourages them to violate the law. Plaintiff may proceed under that aegis.

The Mangini approach provides a vehicle for more aggressive challenges to cigarette advertising and promotion - through both legislation and litigation. ${ }^{6}$

\section{Smokeless tobacco advertising}

Congress enacted the Comprehensive Smokeless Tobacco Health Education Act ("Smokeless Tobacco Act'”), 15 USC $\$ 4401$ et seq, in 1986 to "inform the public of any dangers to human health resulting from the use of smokeless tobacco products." Id $\$ 4401(\mathrm{a})(1)$. Like the Cigarette Act, the Smokeless Tobacco Act establishes national warning label requirements. Id $\$ 4402$. However, it affords state and local governments significantly greater latitude

${ }^{6}$ This theory could be particularly useful in challenging cigarette company circulation of backpacks, $\mathrm{T}$-shirts, and other promotional products targeted largely toward young people. 
to regulate advertising than the Cigarette Act does.

The preemption provision of the Smokeless Tobacco Act provides, in relevant part:

No statement relating to the use of smokeless tobacco products and health, other than the statements required by ... this title, shall be required by any State or local statute or regulation to be included on any package or in any advertisement (unless the advertisement is an outdoor billboard advertisement) of a smokeless tobacco product.

15 USC $\$ 4406(b){ }^{?}$

This provision bars state and local governments from modifying or supplementing federal labeling laws. But it does not prohibit these governments from enacting other regulations regarding the advertising or promotion of smokeless tobacco. The Senate Committee report on the Smokeless Tobacco Act makes this clear:

[B]y including provisions in [the Act] which require health warnings on packages and advertisements for smokeless tobacco products, and by preempting State and local laws requiring additional health warnings, [the Committee] does not intend to preempt a State's ability to control the promotion or advertising of [smokeless] tobacco products and does not intend to preempt product liability suits in State or Federal Courts based on failure to warn.

S Rep 209, 99th Congr, 2d Sess 14, 1986 USCCAN 7, 13 (emphasis added).

\section{Advertising other tobacco products}

Congress has not addressed the advertising or promotion of roll-your-own cigarettes, cigars, or pipe tobacco. ${ }^{8}$ Therefore, state and local regulation of advertising for these tobacco products is not preempted under federal law.

THE FIRST AMENDMENT AND TOBACCO ADVERTISING

State and local laws that regulate tobacco advertising without being preempted must also pass First Amendment review. These laws regulate commercial speech. The constitutionality of a restriction upon commercial speech is reviewed under the four-part test set forth in Central Hudson Gas \& Electric Corp vs Public Service Commission of New York, 447 US 557 (1980). See also US vs Edge Broadcasting Co, 113 S Ct 2696, 2702-03 (1993); Edenfield vs Fane, 113 S Ct 1792, 1798-1804 (1993); City of Cincinnati vs Discovery Network, Inc, $113 \mathrm{~S}$ Ct 1505, 1513-16 (1993).

The first step in the Central Hudson analysis is to determine whether the regulated advertising is constitutionally protected. Central Hudson, 447 US at 563-64; Edge Broadcasting, $113 \mathrm{~S} \mathrm{Ct}$ at 2703. The First Amendment does

7 Billboards were excluded from the Act's warning requirements because smokeless tobacco products rarely were advertised on billboards at that time. See 132 Congr Rec 1329 (statement of Rep Waxman). See also Public Citizen vs FTC, 869 F 2d 1541, 1544, 1555-57 n 31 (DC Cir 1989).

8 Some "little cigars" are, however, subject to certain provisions of the Cigarette Act. 15 USC $\$$ 1332(7), 1335.

not protect advertising that is deceptive or concerns unlawful activity. See FTC vs Brown \& Williamson Tobacco Corp, 778 F 2d 35, 43 (DC Cir 1985). See also Ibarez vs Florida Department of Business \& Professional Regulation, 114 S Ct 4503, 2088 (1994). Therefore, tobacco advertisements that include false statements or promote illegal activity - such as smoking by minors - may be freely regulated without constitutional problems. See Bystom vs Fridley High School, 822 F 2d 747, 753 (8th Cir 1987) (upholding ban on advertisements for tobacco and alcohol in student newspaper because protection for commercial speech "does not extend to advertisement of products that are themselves illegal"). See supra, at 13-14 (discussing deceptive tobacco advertising).

If an advertisement is constitutionally protected, the government must identify a substantial interest underlying its regulation. Ibanez, $114 \mathrm{~S} \mathrm{Ct}$ at 2088; Central Hudson, 447 US at 564; Edenfield, $113 \mathrm{~S} \mathrm{Ct}$ at 1799-1800. Protecting the public health is such an interest. However, state and local laws regulating cigarette advertising for health reasons are preempted under the Cigarette Act. State and local governments must therefore identify another substantial interest that will be served by the restriction on cigarette advertising. One example is the government interest in enforcing laws that prohibit the sale of tobacco to minors. On this basis, some state and local governments are enacting broad bans on billboard advertising of tobacco products.

The third and fourth steps in the Central Hudson test require that the restriction on commercial speech directly advance the asserted government interest and that the fit between the restriction and the government interest be reasonable. Central Hudson, 447 US at 564; Edge Broadcasting, $113 \mathrm{~S} \mathrm{Ct}$ at 2704. These hurdles must be cleared if a law restricting tobacco advertising is to survive First Amendment scrutiny.

For instance, a city might ban cigarette advertising on the theory that discouraging smoking would reduce littering. However, the tobacco industry could argue that the ban does not directly advance the city's asserted interest in litter reduction. See Discovery Network, 113 $\mathrm{S} \mathrm{Ct}$ at 1511 (accepting city's assertion that it had a substantial interest in safety and aesthetics of city streets but finding that interest to be insufficient justification for banning newsracks dispensing commercial handbills). The tobacco industry could also argue that the fit between such an advertising ban is not proportionate to the city's asserted goal of reducing litter. See Board of Trustees of State University of New York vs Fox, 492 US 469, 480 (1989).

In contrast, the tobacco industry would be hard-pressed to challenge a ban on placement near schools of billboards for products that may not legally be sold to minors. The government has a substantial interest in enforcing laws that prohibit drinking and smoking by minors. Restricting billboard advertisements near schools, where large numbers of 
students are likely to see them several times a day, directly advances the government's interest. Moreover, it is related to the government's objective of deterring minors from drinking and smoking. To date, the courts have not been asked to decide whether a ban on tobacco billboard advertising is proportionate to the government's interest in stopping the illegal sale of tobacco products to minors.

\section{Conclusion}

In sum, state and local governments retain considerable authority with respect to regulating sales of tobacco products. Bans on sales to minors are nearly universal already, although more effective enforcement of such bans is being encouraged by the federal government and should be pursued by state and local authorities. Efforts to restrict vending machine sales of cigarettes have been successful in several states, and bans on the sale of tobacco products at locations that may increase their accessibility to minors may be legally feasible.

Increased state and local regulation of advertising and promotion of tobacco products is also possible, although such legislation must be carefully drawn to avoid conflicts with federal statutes and the First Amendment. General laws that are grounded in the traditional police powers of the state and that are not targeted directly at cigarettes are most likely to be upheld by courts if challenged.

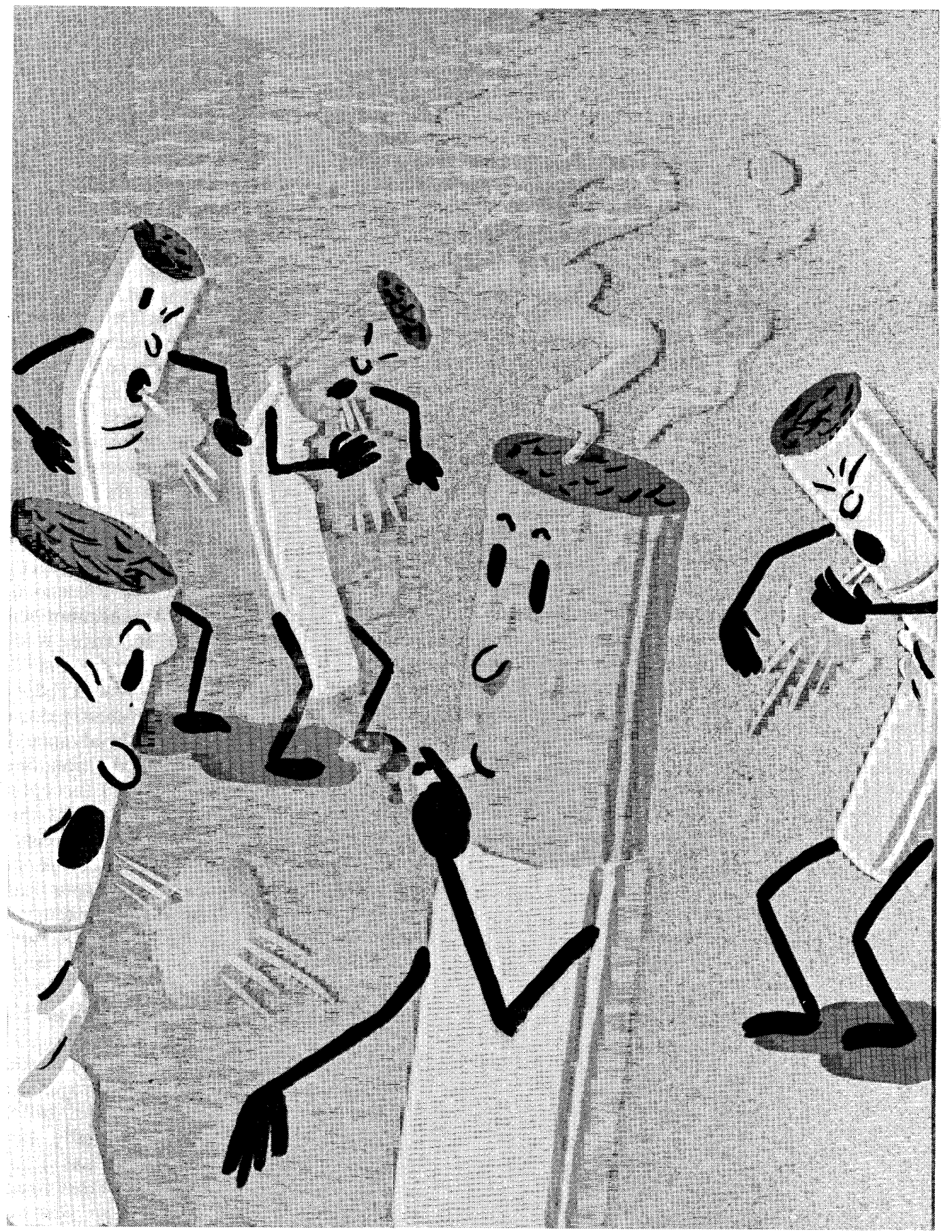

